\title{
Unmanned Bonds: the Impact of Self-Automated Service on Consumer Loyalty
}

\section{Maik Huettinger, Vytenis Cubrinskas}

ISM - University of Management and Economics

Arkliu st. 18, LT-01129, Vilnius, Lithuania

e-mail:huettinger@v4ce.net,vytenis.cubrinskas@yahoo.com

crossref http://dx.doi.org/10.5755/j01.ee.22.2.317

Self-service is a type of service, where a customer can perceive his/her buying action with more self-involvement. Since a customer has an impact on the quality of the creation of the service experience, it naturally has an effect on the image of the company. The loyalty to a store or a brand is affected by the customer's experience as well. This effect on customer attraction to a company is an important variable in business. The literature therefore identified four main loyalty forms in the area of consumer behavior: brand loyalty, vendor loyalty, store loyalty and service loyalty.

Before installation and during the usage of self-service automated systems, it is useful for vendors to know if it would not discourage some customers. Yet, the affect of self-service option deployment on customer loyalty is not known. The purpose of the research was to investigate and relate certain consumers' traits to the usage/preference of self-service technology. It was discovered that, on average, more than $50 \%$ are active users and prefer ASS to personal service. The discovery of enhanced attitude towards a company, which offers self-service option, suggests opportunities of new type of loyalty development.

The structure of the paper is determined by the scope of the research purpose. In the first two parts of the paper, the theoretical framework behind the proposed approach was evaluated. The methodological and analysis chapter discusses consumer behavior from a service and store loyalty perspective. The hypothesis of this paper is that the choice of self-service technology leads to a trait in that technology, resulting in a positive attitude towards the company. The empirical research is based on a sample of 547 respondents and addresses the potential existence of technology-driven loyalty. Usage patterns and opinions are assessed. Comparison of means and binomial regression were used to test for significant linkages between traits and usage/preference for self-service technologies.

Research objectives were: a) review the literature about consumer interaction with self-service technologies and identify missing gaps/contradictions in existing knowledge b) describe consumer traits, that are influential for certain attitudes towards self-service technologies c) evaluate the importance of different consumer traits for preference and usage, using a statistical analysis and data from the survey; classify the traits on demographical parameters and d) provide recommendations for further exploration and implications for practical application.

The findings indicate that consumers with a positive attitude towards self-service machines express an increased attraction to service providers. However, the frequency of usage has not a significant impact on the perception off self-service technology attributes. Furthermore, the findings show that the perceived advantages of self-service technology are homogenous among various users groups. The enhanced attitude towards a company, which offers a self-service option, suggests opportunities of a new type of loyalty development. Moreover, customers were grouped by demographic variables, indicating that younger and higher income customers are more loyal to technology-related service attributes.

Keywords: self-service, consumer behavior, consumer loyalty, automated service, personal service.

\section{Introduction}

The increasing presence of self-service points in financial, communication, retail and other sectors has sparked an academic interest in technology_and customer interaction. In published studies, the acceptance and rejection of machines (Parasuraman, 2000, Curran et al, 2003), situational and other influences on usage (Dabholkar and Bagozzi, 2002), satisfaction factors (Meuter et al, 2000) and the effect of age (Dean, 2008) were studied. However, the impact on loyalty of self-service was covered only partially (Selnes, 2001).

This article is relevant to consumer behavior researchers and self-service systems developers. Although loyalty is not a new or unstudied topic, the attachment to systems, in which there is no personal contact is poorly researched in the Lithuanian market. Therefore, the findings and recommendations are primarily useful for marketing studies and practical decisions for vendors.

Before the installation and during the usage of selfservice automated systems, vendors would like to know if some customers become discouraged. There is also the potential for a positive effect on customer attraction. However, very little research has been done on the effect of customer loyalty from self-service option deployment.

The purpose of the research: to reflect Lithuanian consumers' perceptions of automated self-service from the perspective of technology-driven loyalty ${ }^{1}$; and provide a base, as well as dataset, for further research.

\section{Research objectives:}

1) In-depth literature review on consumer interaction with self-service technologies and identify missing gaps/contradictions in the existing research.

\footnotetext{
${ }^{1}$ Technology-driven loyalty is a term of this paper. It means type of loyalty that is technology-related, as opposite to person-related.
} 
Maik Huettinger, Vytenis Cubrinskas. Unmanned Bonds: the Impact of Self-Automated Service on...

2) Specify research directions, based on the analyzed literature and practical applicability point of view. Describe consumer traits that are influential for certain attitudes towards self-service technologies.

3) Evaluate the importance of different consumer traits for preference and usage, using statistical analysis and data from surveys. Classify the traits within demographical parameters.

4) Provide recommendations for further exploration and implications for practical application.

Customer loyalty, in times of increasing competition, has become an important concept in marketing studies. Companies are adopting loyalty programs to retain customers. Consumer behavior and especially loyalty is a key element of strategic management, allowing companies to create a sustainable advantage in a highly competitive environment. Loyalty is largely associated with confidence and allows companies to set prices a bit higher - which allows for more investment in research and development.

According to Oliver (1999), loyalty is a "deeply held commitment to rebuy or repatronize a preferred product/ service consistently in the future, thereby causing repetitive same brand or same brand-set purchasing despite situational influences and marketing efforts having the potential to cause switching behavior".

Consumer loyalty has become, in times of increasing competition, an important concept in marketing research. Companies are running loyalty programs to retain customers. Consumer behavior, and particularly loyalty, is a core element of strategic management as it enables companies to build up a sustainable advantage in a highly competitive environment. Significant loyalty is related to trust and allows companies to charge slightly higher prices: a benefit which allows them to invest more in research and development.

Research objectives were met: related literature review led to the raising of a hypothesis and testing with sample data. Moreover, the trait of interest was identified and measured. Results of analysis enabled the drawing of conclusions and provided a solution recommendation to the problem.

In a separate part of the questionnaire on self-service system characteristics, respondents identified a number of key advantages and disadvantages. This practical advice to both producers and users (developers), which feature selfservice systems, should be highlighted in advertising to improve or transform the opinion about them.

First, the self-service system feature perception is not significantly different between those shoppers who frequently use technology, and those who are reluctant to use them. This reflects the opinion of the technology at a relatively objective, undistorted level. However, it is important to know exactly on what characteristics selfservice systems' developers should focus on in order to turn potential customers into regular users.

Second, the perception of the advantages in the different user groups (frequent and occasional users) is almost identical. People believe that the self-service option is faster, more convenient and provides greater privacy. In addition to these, a unique understanding is that the use of self-service machines is fun. Interestingly, frequent users distinguish the convenience as the main reason for using while non-users think that usage is driven by the fun that the users experience. The logical conclusion is that, in order to encourage more consumers to try self-service, speed and fun must be stressed less. Rather, the emphasis should be put on the convenience and easiness of fulfilling the need. To put it simply: if consumers know that the self-service option is not just a playful tool for paying, but really a high performance platform, focused on the needs of customers, the company can expect more consumers who are able to decide between service type alternatives depending on the situation, rather than follow the "I always do so" rule.

On the other hand, a significant portion of respondents named the lack of functionality (or functions) of selfservice machines. Functionality may deter some users who are concerned about the low flexibility (discount card) or bonuses that are lost (discount coupons). These are the standard complementary activities carried out by staff. Therefore, another marketing message should be to strengthen the technical (ease of use and multi functionality) side, ensuring that customers will not lose any of the services and accessories.

The most important question about the new technology is the actual consumer segment, which is most likely to be interested in trying it. Therefore, demographic details of respondents were collected and classified within certain categories. The sample is sufficiently diverse in terms of demographics, so a broader generalization could be done. More detailed data is presented in charts. It is not surprising that marketing efforts should be aimed at younger (less than 35 years old) people. Education is not a "one-way" factor: students and university graduates are more attracted to innovation - the research results confirm this intuition. On the other hand, those who have high school or college educations are less enthusiastic for selfservice systems.

Although both types: college and university education is considered higher (tertiary), there is quite a significant disparity of opinions between graduates. Difference of preferences (for self-service or for regular personal service) is over $20 \%$ between the two education categories. The category of "incomplete higher education" is potentially inaccurate due to wording in the questionnaire. It may be that some respondents who are still in the studying process indicated this type of education, instead of marking their highest completed level.

Another aspect is the loyalty to technological solutions. Based on observations, neither age nor education is linearly dependent features. However, family composition plays a fairly important role. One can guess that there are some psychological reasons. For example, behavior is uneven between young people who already have their own families and those who do not have it yet. Similarly, people who live with their parents and those who live alone, respond differently. Usually people, who are less family-involved, expressed more agreement to "technology-driven loyalty" statements. Theoretically, the use of self-service can be associated with the level of personal autonomy in the broader sense.

Finally, the income ratio is a significant indicator of loyalty to technological solutions. The technology-based 
loyalty trait is almost linearly dependent on monthly income: the higher it is the more "technology-loyal" the respondent is. Another important observation is that the highest income category $(>2000 \mathrm{Ltl})$ respondents are about $20 \%$ more likely to choose self-service instead of employee service. This is an important message - there are two customer segments, where self-service promotion is effective. These segments include: a) young, independent people or b) people with higher income (regardless of age). These groups are likely to appreciate the new alternative of self-service automates. This leads to a more favorable attitude towards a company and increases loyalty by fulfilling the specific needs of customers.

\section{Theoretical Framework}

In a fundamental study, Cunningham (1956) showed the importance of brand loyalty as an element of the consumer behavior process. Other scholars have stressed upon vendor loyalty, store loyalty and service loyalty (Dick \& Basu, 1994). However, the concepts of loyalty are often mixed, which inspired various scholars to point out the differences (Jacoby, 1971; Jacoby \& Kyner, 1987; Newman \& Werbel, 1973).

Jacoby and Kyner (1973) attempt to explain brand loyalty according to six necessary and sufficient conditions. It includes the notion that a verbal statement (intention) to buy does not automatically result in a purchase. Loyalty has therefore to be (a) biased (nonrandom) and be followed by a (b) behavioral response. It has to occur at, minimum, (c) two different points in time and be made by a (d) decision making union which can either be the user, purchaser or even by a collection of individuals. In order to be considered as brand loyal, the decision-making unit has to (e) select at least one brand out of a set of brands containing competing alternatives. In addition it needs to be a ( $\mathrm{f}$ ) function of the decision making, evaluative processes. Jacoby and Chestnut (1978) confirm that most studies have focused on behavioral outcomes, rather than on measuring what went on in the minds of customers. Prior studies determined therefore the frequency of purchase, the proportion of the purchase devoted to a given brand and the probability of purchase (Caruna, 2000).

Service loyalty is defined as the degree to which a consumer is willing to use a service provider on a regular basis, possesses a positive attitudinal disposition towards this provider, and does not even consider using another service provider for this service (Gremler and Brown, 1996). According to Virvilaite et. al. (2009), service pricevalue, service quality and customers' service are the main determinants of customers' loyalty.

Bloemer and de Ruyter (1998) define store loyalty as the biased behavioral response expressed over time, by some decision making unit with respect to one store out of a set of stores, which is a function of psychological processes resulting in brand commitment. This definition is an adaptation of the brand loyalty definition of Jacob and Chestnut (1978) by adding store commitment. Store commitment is defined as the pledging and binding of an individual to a store. This can be achieved by the usage of loyalty cards, which have gained worldwide popularity. Recent studies (in Lithuania) have, however, shown that loyalty programs rather stimulate sales than enhance loyalty (Bagdoniene, \& Jakstaite, 2007).

Unlike store loyalty, which focuses on the relationship of an individual to a retail establishment, vendor loyalty is rather important for industrial goods and reflects the fidelity an organization gives to a supplier. For industrial products, the switching costs are significantly higher than for consumer goods, evolving into a "pair of commitments by two parties over time (Jackson, 1987). Customer switching behavior itself is determined by factors supporting customer-switching behavior as well as by factors, which are repressing customer-switching behavior (Zikiene \& Bakanauskas, 2009). Bagdoniene and Jakstaite (2007) investigated Lithuanian consumers' loyalty in three retail store chains. They have discovered that the loyalty programs (cards), currently applied, do not really foster loyalty. They barely pull consumers to certain preference, beyond pure economical reasons. However, the true loyalty does not cherish as consumers often $(\sim 30 \%)$ own few loyalty cards and purchase according to offerings. Hence, they are price-, but not brand-dependent. An issue of loyalty nurture may be of interest in this investigation.

Day and Jacoby suggest a two-dimensional construct, including both behavioral and attitudinal aspects (Day, 1969; Jacoby, 1971). Attitudinal aspects deal with various feelings and emotions from an individual's overall attachment with a product, service or organization, defining the degree of loyalty (Fornier, 1994; Hallowell, 1996). Consumers must hold a positive attitude towards a product or service in order to use it on a frequent basis (Bove and Johnson, 2009). Behavioral aspects are related to the definition of loyalty, which is suggested by the service management literature. It focuses on repeat purchase services of the same provider, increasing the scale or scope of relationship, or buying on recommendation (Yi, 1990).

Olivier provides an overview about relationship satisfaction and loyalty (Oliver, 1999). Loyalty and Satisfaction can therefore be described as separate manifests of the same concept, the first one being the core concept of the second one or simply as a component or element. Whereby most authors see satisfaction and loyalty somehow linked, Prus and Randall (1995) explicitly exclude satisfaction as a sufficient criterion. Bagdoniene and Jakstaite (2006) see "the interaction of enterprise and customer determined by particularities of goods (services)" as having a higher impact on customer loyalty than satisfaction. However, the existence of a possible relationship of both concepts would be essential, as various studies have already proven a strong link between customer satisfaction and financial outcomes (Keiningham et al. 1999, Andereeson, Fornell and Lehmann, 1994). Satisfaction has furthermore a positive relationship with the profitability of a firm (Hallowell, 1996).

Oliver has also adapted his own definition, which includes both attitudinal and behavioral aspects by adding the act of consuming (Oliver, 1997; Oliver 1999). In 1997 he introduced a four-stage loyalty model (cognitive, affective, conative and action), suggesting that different aspects of loyalty do not emerge simultaneously, but rather 
Maik Huettinger, Vytenis Cubrinskas. Unmanned Bonds: the Impact of Self-Automated Service on...

consecutively over time (Blut et al., 2007). His approach identifies loyalty phases and suggests that consumers can become loyal at various stages (Oliver, 1999):

During the cognitive phase, the consumers base their decision on brand attribute information, which is available to the consumer. Consumers base their decision on recent experiences or on vicarious knowledge. Affective loyalty is based on a positive attitude (liking), which consumers have developed towards a brand. In case consumers feel dissatisfied with a specific brand, the selection of an alternative brand is likely. At the conative stage (or behavioral disposition), loyalty development is determined by repeated events of positive affects toward a brand and suggests a brand-specific commitment to repurchase. In the final action loyalty stage, the intention of the conative stage is transferred into action. The mechanism is termed "action control sequence" (Kuhl \& Beckmann, 1985).

Dick and Basu (1994) define loyalty as the "relationship between relative attitude and repeat patronage". Relative attitude explains why consumers might hold a positive attitude towards one brand, but due to comparable or greater attitude extremity towards other brands, the brand is not frequently bought. The degree of relative attribute is determined by the degree of attitudinal strength (extremity towards a brand) and the degree of attitudinal differentiation (perceived differentials of brand attributes). Both authors suggest the final degree of loyalty (loyalty, latent loyalty, spurious loyalty, no loyalty) to a brand to be determined by the relative attitude and by repeat patronage.

A problem in the existing literature about Self-service technologies is the lack of direct investigation about loyalty. Curran et al., (2003) notes that a "very real concern for managers is the potential loss of brand identification with the increasing use of technology in the service encounter. Given this possibility, the potentially negative ramifications of incorporating more technology into the service environment must be explored further." The aspect of acceptance or rejection and the influence of situation to technology anxiety are explored to some extent. However, many authors point out, that there is still space for research in practical self-service implementation. "Future research must study the impact of the outcomes of SST use on the level of loyalty displayed by the customers" (Weijters et al., 2007). Other scholars point out similar problems. "How does the lack of human contact affect loyalty, and what are the determinants of service loyalty regarding SSTs? Is it easier for customers to switch, and if so, how can loyalty be built into these situations?" (Meuter et al., 2000).

Yet, the usage of ASS is related to the loyalty or attraction to a specific company. In certain situations the SST is not an alternative, but the only option. In such a case, a customer is "forced" to use the technology. Reinders, Dabholkar \& Frambach (2008) addressed the consequences of forced SST usage. Their first conclusion is that forcing consumers to use TBSS leads to an unfavorable attitude towards both: TBSS and the provider (Reinders et al., 2008). Additionally, forced use results in negative word-of-mouth and switching intention. Conversely, attitudes toward TBSS are influential for positive word-of-mouth and also affect the switching intentions (better attitude towards TBSS reduces the intention to change either the point-of-sale or the route).
Fred Selnes and Håvard Hansen (2001) discussed the issue of loyalty from the perspective of self-service development. In the service delivery process, the social bond between customers and service employees may be present. However, as the service gets automated, this bond is reduced or completely eliminated. How this phenomenon affects loyalty was one of the main research questions. For the investigation the customers of a particular bank were approached and a sample of 195 people was formed - all of them claiming to have some personal relationship with bank employees.

It was observed that the level of usage of personal service is correlated with loyalty, whereas self-service is not (Selnes \& Hansen, 2001). Another relevant conclusion is that the transformation from personal service to selfservice will have a positive effect on social bonds in highcomplexity relationships (Selnes \& Hansen, 2001). Authors mark the need to investigate the mechanisms of how the social bonding processes can be imitated, or even improved through technological solutions. Self-service systems may vary in their reliability and functionality, which are very likely to affect their impact on customer loyalty (Selnes \& Hansen, 2001).

Research about Lithuanians interaction with innovations, especially self-service platforms is scarce. No academic paper, discussing interaction with self-service technologies (with the exception of e-banking and online shopping) was found at the time of writing this paper. According to the Lithuanian Consumer Institute no study concerning selfservice technologies was ever performed at that institute. Research/ Consulting firms such as Baltic Surveys, TNS Gallup, AC Nielsen stated, that they never had an order for research, concerning consumer and SST relation.

\section{Hypothesis}

A self-service gas station or self-service checkout has principally the same features in terms of personal service as bank employees. They are the subject for the social bond between the customers and personnel. However, as the latter gets replaced by automated self-service, can this loyalty transfer "in one piece" to sophisticated technology?

McKenzie (2006) concluded that among Estonians, there is "an expectation for the retailer to allow the shopper to exert their own sense of shopping capabilities and, therefore, it is needed to provide self-service tools and information". This conclusion attempts to suggest that in order to attract or keep the customers, companies must deploy the automated self-service option. Additionally, Meuter et al. (2000) marked, that the loyalty to a company, that was lost due to low performing personnel, may be retrieved with sophisticated ASS.

Therefore, low satisfaction leads to the loss of loyalty over competitors, who offer higher quality personal service. Sophisticated SST may retrieve the loyalty; compensating for low performing trained professionals (Meuter et al., 2000). Selnes \& Hansen (2001) observed that the level of usage of personal service has a strong positive correlation with loyalty, whereas self-service does not. So the question is: can technological superiority over competitors offer customers value and foster loyalty comparable to that of personal service. According to 
Dovaliene \& Virvilaite (2008), an increase of costomer value can create and maintain long-term relationships among consumers and retailers. Weijters et al. (2005) suggested measuring the direct result of the outcomes of SST usage on the level of loyalty displayed by the customers. It is noteworthy that high and low previous usage does not significantly influence the attitude towards providers (Reinders et al., 2009).

\section{Methodology and Analysis}

In this study, consumer loyalty is studied from a service and store loyalty perspective. Conceptually, service loyalty is related to the product and store loyalty is related to the brand. The product of service is the interpersonal relationship. While there are measures and techniques for development of this relationship, loyalty to service without personnel is not a familiar construct. Therefore, the article is intended to shed light on this special field for consumer behavior research.

Interpersonal service (like that from a barber or doctor) is out of the scope of this study, as such service is impractical to be done by oneself. However, some other services (cashier, gas station assistant) are available as selfservice. This type does not require a human employee and defers all the related issues to the interaction with automated machines. Such self-service technologies are referred to as SST in the text. Specifically, those include the self-checkout and self-service gas station. Online services are not included as they are practically different types of self-services (interaction with a computer, but not with a special automate).

The research consists of literature review, theoretical model, survey and statistical analysis. The questionnaires were split into two settings: a portion (54\%) of questionnaires was filled-out on the Internet, the other - in the field $(46 \%)$. In total 547 completed forms were collected with a gender distribution of 54, $8 \%$ being females. The necessary number of observations for a type of statistical analysis, used in this research, is 300 (Dikcius, 2005).
Respondents were almost equally distributed in terms of preferred type a) personal or b) automated self-service usage. The sample consisted of inhabitants of Vilnius - the capital of Lithuania. Mainly respondents were young $(<26)$ with higher education and a monthly income of 1500 Litas or more.

The questions were formulated as statements, exposed for evaluation in the 5-point Likert scale. Furthermore, demographical data was collected, together with additional insights about perceived SST attributes (speed, convenience, etc.). In a further step, the answers were coded, grouped and analyzed by using various statistical tools (SPSS). The comparison of means between groups of SST users (and non-users), correlation analysis, and Logit regression were used.

The theoretical background for hypothesis testing was formulated from the previous research and adjusted with those SST which the respondents are most likely to have faced in their daily operations: self check-out and selfservice gas stations or car washes. A supplementary set of questions covered technologies that are desirable in the Lithuanian market, but which are yet not broadly available.

Theoretical construct of the link. Technology-driven loyalty was developed as a trait which a consumer may possess. The strength was measured by using a set of questions with the Likert scale. Later the score was assigned to one of two poles: either attracted to technological solutions or not. As shown in Figure 1, the certain choice of technology leads to a trait of technology loyalty and later transforms into loyalty to a company.

Sample split. Meuter noted that the online survey participants can have a generally more positive attitude toward SSTs than the general population (Meuter et al., 2000). To cope with this, researchers Selnes \& Hansen (2001) used a sample split into internet and non-online bank service users. "This procedure, we believe, increased variation in our independent variables" (Selnes \& Hansen, 2001). To reduce (or eliminate) the biases, the field survey was performed with the objective of reaching a diverse (in terms of: education, occupation, age) population as well as to ensure the representation of genders and various income levels along with family profiles.

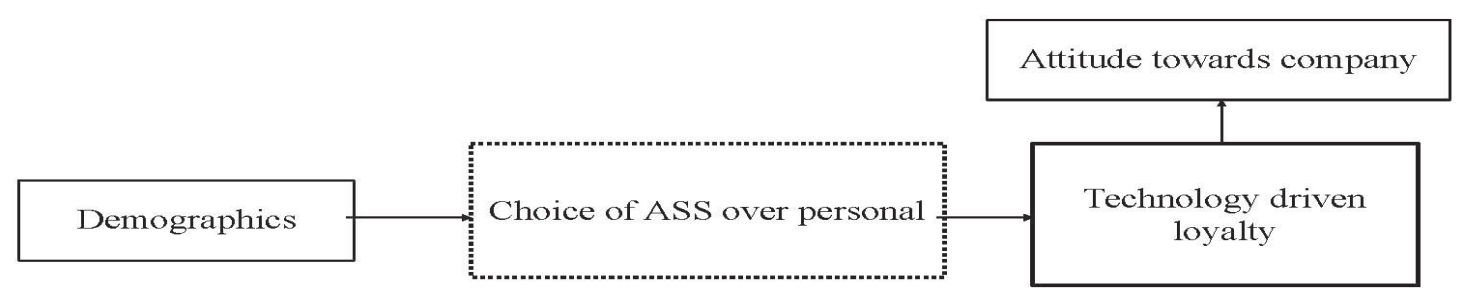

Figure 1. Theoretical construct (ASS - Automated self-service)

Sampling Criteria. As mentioned earlier, the target of the survey is a diverse sample of the public. Therefore, attention was paid to selecting respondents with as many different demographic characteristics as possible. They were targeted towards not only young peers, but also to some institutions with various types of occupations (technical, creative and similar) and demographical groups (age, gender). The field target was intended to ensure variety in occupation, age, gender equality, and variations in education and income as well. The previously planned division of the field sample into three parts (settingspecific) was later adjusted for more sections, as the time consumed/response rate was not good enough to continue at the present pace. The adjusted setting was widened by visiting more points of concentration: (a) two shopping malls, (b) bus/train station, (c) International airport, (d) 
Maik Huettinger, Vytenis Cubrinskas. Unmanned Bonds: the Impact of Self-Automated Service on...

Public Clinic, (e) Social Security Office, (f) Vehicle Registration office, (g) City Municipality, (h) Labor Exchange, (i) public transportation lines and (j) the National Registry Center.

Since people were approached in conditions where they generally are waiting to be served by a particular institution, the refusal to participate rate was low. Overall, the response on average was $60 \%$.

Analysis of Technology driven loyalty

Technology driven loyalty relation to the usage of ASS technologies was analyzed using an independent samples t-test. Results are: $\mathrm{t}=-5,198$ (at 0.000) for selfservice checkout. $\mathrm{t}=-3,207$ for self-service gas station/carwash (at 0.001). Therefore, it is concluded, that the link between variables exists. The absolute differences of means are: -0.59806 (SCO); -0.35972 (SGS), suggesting that actual usage of technology corresponds to the score of technology-driven loyalty.

Furthermore, the Student's t-test (comparison of means within two groups) was applied for relation between T-DL and the free choice of service type when there is an alternative present. $\mathrm{T}=-9,099$, marking an even greater significance, and the absolute difference is -0.96038 . This leads to the conclusion that a subject with a preference for ASS (to PS) also reported a higher T-DL mean. Therefore, the null hypothesis (there is no relationship between usage and loyalty) is rejected. The test results are shown in Figure 2 above.

\begin{tabular}{|c|c|c|c|c|c|c|c|}
\hline & & B & S.E. & Wald & df & Sig. & $\operatorname{Exp}(\mathbf{B})$ \\
\hline \multirow{7}{*}{$\begin{array}{l}\text { Step } \\
\text { (a) }\end{array}$} & 1GND & .417 &, 215 & 3,754 & 1 &, 053 & 1,517 \\
\hline & $\mathrm{AGE}$ &, 158 &, 105 & 2,252 & 1 &, 133 & 1,171 \\
\hline & EDU &, 098 &, 106 &, 856 & 1 &, 355 & 1,103 \\
\hline & FAM &,- 130 &, 113 & 1,320 & 1 &, 251 &, 878 \\
\hline & INC &, 119 &, 089 & 1,770 & 1 &, 183 & 1,126 \\
\hline & xTDL &, 452 &, 097 & 21,938 & 1 &, 000 & 1,571 \\
\hline & Constant &, 188 & 974 &, 037 & 1 &, 847 & 1,207 \\
\hline
\end{tabular}

Figure 2. T-test Technology driven loyalty (Age, Education, Family, Income)

\section{Results}

The results from the analysis suggest that there is a connection between technology usage and reported technology-driven loyalty. These findings are notable, as (Weijters et al. 2007, Reinders et al. 2008) argued that such a link does not exist. However, it must be mentioned, that the concept of loyalty must be interpreted with reservation here. It was also found, that more innovative people are on average more attracted to companies with ASS services.

\section{Discussion}

This article covers the previously unexplored aspects of consumer interaction with self-service technologies, namely - the change in loyalty due to the automated service.

As hypothesized and discussed in the analysis section, the phenomenon of enhanced loyalty can be detected. Customers reported a different attraction to companies which offer the SST option. Those, who use SST, report being more attracted, than those, who use not.

To cover this finding in more details, a few things must be stated. First, the reported attraction does not necessarily constitute the existence of loyalty as such. As predefined in the literature review, loyalty is not just intentional (declared), but a repeated and conscious decision to repurchase at the same store (company). Yet, the statements were compared to "actions", and it proved to be linked. Hence, the attitude has an impact on behavior at the examined setting. Furthermore, it can be concluded, that better attitude towards SST results in more usage and the user has a better attitude towards the company, which provides the service.
Therefore, the following paragraphs discuss the finding in these aspects: specific type of loyalty, recommended communication message and target audience. After reading this section, one might consider the applicability of findings and proper ways of implementation. In Figure 3 the relationship of age and service usage is displayed. As seen, people up to 35 years old generally prefer automated service.

\section{Loyalty to service}

It is common to consider customer service as something that is based on human interaction. Most consumers link the concept to friendly employees serving customers who appreciate it and come back to the store. Nonetheless, other surroundings, like music, cleanness, ergonomics and numerous other factors are important as well. One such factor is the option to get served by your self - that literally drives a customer to achieve a service that complies with their expectations.

In Figure 4 the shifting preference between personal and automated service dependency from income is shown. It is visible that automated self service is more than 1.5 times more popular among the highest income category respondents, compared to the lowest. 


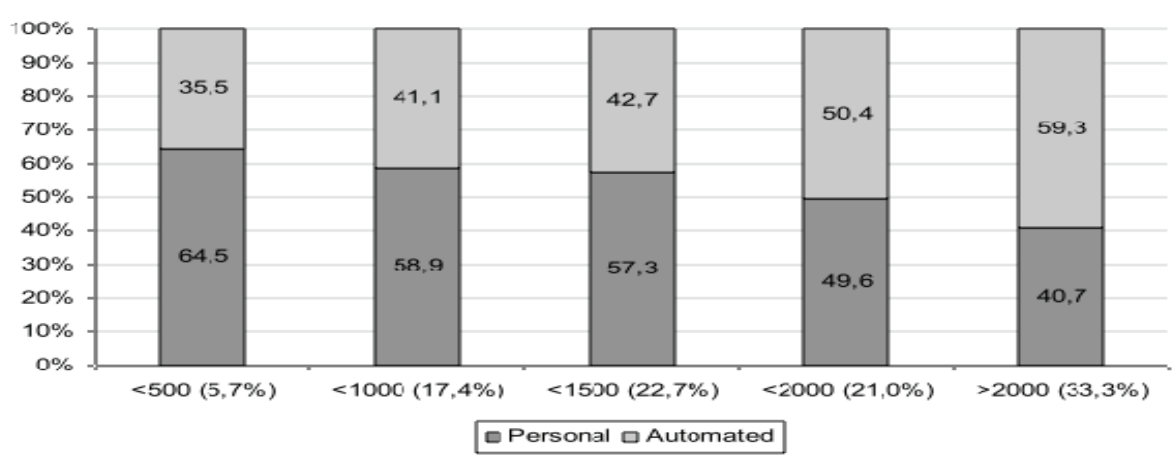

Figure 3. Service preference and age

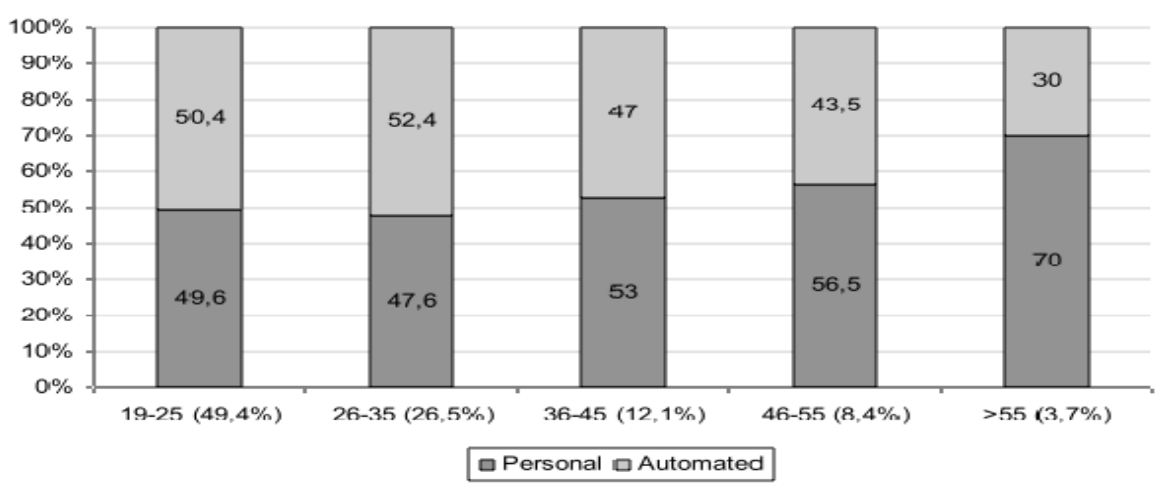

Figure 4. Service usage and income

Although the self-service option is unimaginable in certain settings (dentist) or hardly welcome in some others (high class restaurant), there are many service points (oneitem or routine purchase) where customers benefit from doing things themselves instead of being dependent on staff. Likewise, self-service reinforces the concept of customized service. Yet, what does the term technology driven-loyalty mean?

In the survey, it was defined as a set of conflicting statements. First, an automated self-service offering company is more attractive as it provides the opportunity to satisfy specific needs. Second, a self-service without alternative personal service, is perceived as discrimination by some customers. Third, customers like a company which is constantly renewing its facilities and service delivery means. Fourth, a company which offers too many novelties is unattractive, because customers waste time when learning how to use them. Fifth, customers prefer some companies particularly for new and convenient service delivery solutions. Finally, new service delivery technologies increase nothing but confusion.

These statements represent the opinion of a respondent, which was later correlated with actual behavior. Respondents were divided in two categories: those who claim choosing Self-service whenever possible and those who choose personal service instead. By this correlation to questions, an observation is later plotted and a numerical output is produced. The three traits (innovativeness, personal service preference and technology-driven loyalty) are displayed in Figure 5. The left hand side shows results from a web survey (biased for younger) and the right hand side shows results from the field. At this point, it is only clear that the T-DL trait varies in age groups. Therefore, it should not be concluded that only younger people are potentially technology-loyal.

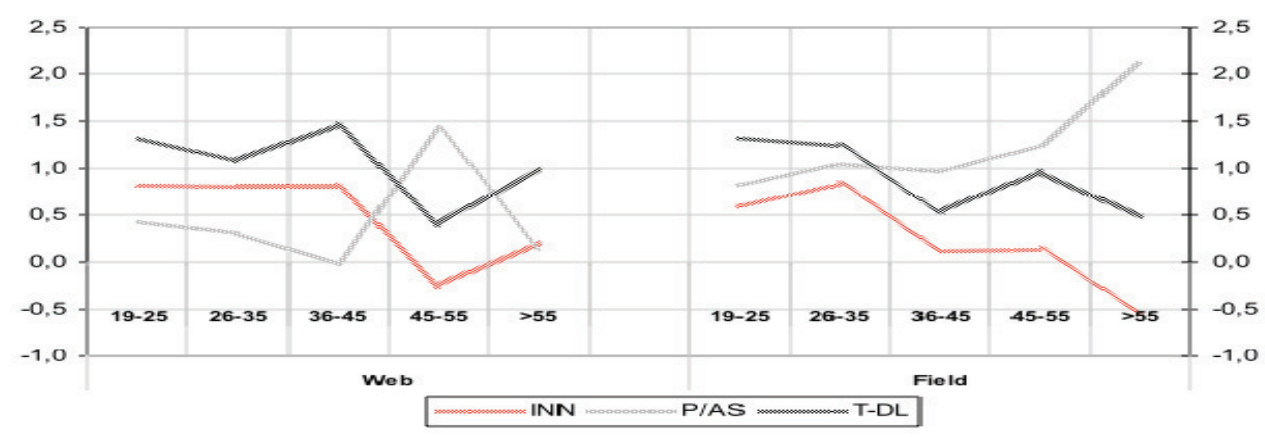

Figure 5. Traits and age (innovation, personal/automated service, technology driven loyalty) 
Maik Huettinger, Vytenis Cubrinskas. Unmanned Bonds: the Impact of Self-Automated Service on...

People who: a) prefer and b) actually use SST, report a more positive attitude (higher attraction) towards companies with this service option. The t-test result between different user categories is $-9,098$ (at 0,000 significance). This stays true not only for preference, but for behavioral choice (usage) as well. Furthermore, when compared to the personal service priority, the groups also differ. That is not surprising, however. The groups differ such that SST users do not like personal service. The fact draws attention to a specific aspect: there is a segment of consumers, who are not simply intent to try out novelties, but dislike the personal service (for some reasons) and look for an alternative in SST, in this context.

\section{Conclusions}

As was discovered from the question set on SST attributes, respondents pointed out few major drawbacks or benefits. This leads to a practical advice suggestion both for producers and implementers on what features of SST one should strengthen and promote and which one to improve.

First, the perception of SST attributes is not remarkably different between people who use the technologies frequently and those who avoid them. This suggests a rather objectivity of opinion. However, it is important to know what type of benefits of SST one should communicate to new customers and still expect a positive effect.

Second, the advantages perceived by different user groups are almost consistent. People do believe the SST are faster, more convenient and ensure more privacy. Besides these, exceptional is the perception of SST as being fun to use. Interestingly, SST users appreciate the convenience of service while non-users believe it is fun. The logical conclusion is that in order to encourage more users to try out the SST, the marketing message should concentrate less on fun and speed, and more on convenience and goal-achievement. Simply speaking, if customers are aware that the SST is not only designed for playful action at the store, but actually is a properly working platform for better needs fulfillment, a merchandiser might expect more and more users to decide between services, evaluating specific situational needs, instead of sticking to a "regular" service all the time.

On the other hand, a major drawback of SST is the lack of functions (or functionality), followed by "no consultation" of what is natural. Yet, the low functionality may discourage some potential users who may be worried about low flexibility (discount cards) or lost premiums (coupons) when addressing SST instead of personnel. Therefore, another marketing message should strengthen the technical (ease of use and many functions) side of automates to make sure customers are not afraid of being incapable.

The most important issue about new technologies is the actual consumer segment which is most likely to be keen on trying it out. Thus, the research covered respondents demographically in order to later classify and show the patterns of certain categories. The sample is various in terms of demographic description so that the generalization of results can be counted on. The main findings were that marketing efforts should aim at younger (up to 35 years old) people. Moreover, the education factor is not linear: students and university graduates tend to be more attracted to novelties and research results confirm this intuition. However, people with high school or college education are less likely to be SST enthusiasts. More details can be seen in the following illustration. It appears that college and university graduates have different opinions about self-service. Although one would consider both types of education to be not that different, clearly preferences are different for more than $20 \%$ of respondents. The category of "some college education" is likely to be not very precise due to how it was formulated on the Lithuanian questionnaire. It could be that some students-in-progress indicated this type of education.

Another perspective is the very trait of technologydriven loyalty. According to the observations, age and education are not in linearly relationship with this trait. In contrast, family composition plays a quite important role. It may be speculated that there are some psychological reasons (dependent vs. independent young vs. people with children), but generally, people who are less family involved are more likely to express higher scores on the measurements of the TDL dimension. Finally, the income factor is the brightest indicator. Technology-driven loyalty is almost linearly dependent on monthly income: the higher it is, the more TD-loyal a respondent is. Another important remark is that customers in the highest income category (>2000Ltl) are almost $20 \%$ more likely to choose SST over personal service. This carries an important message - there are two customer segments, and addressing them might be fruitful for marketing efforts. Those are young, independent people or people with higher income (whatever the age). These are the groups that are most likely to appreciate the new service option. In turn, this leads to better attitudes towards a company and, supposedly, increases loyalty by satisfying the needs of such customers.

Acknowledgment: We would like to thank Grinvydas Kareiva, Julija Kosareva, Alina Kasponyte, Arturas Liutostanskis, Algirdas Rasimavicius for their contribution.

\section{References}

Anderson, E. W., Fornell, C., \& Lehman, D. R. (1994). Customer satisfaction, Market Share, and Profitability: Findings from Sweden. Journal of Marketing, 58(4), 53-66.

Bagdoniene, L., \& Jakstaite, R. (2007). Estimation of Loyalty Programs from Customer's Point of View: Cases of Three Retail Store Chains. Inzinerine Ekonomika-Engineering Economics(5), 51-58.

Bagdoniene, L., \& Jakstaite, R. (2006). Customer loyalty programs: purpose, means and development. Organizaciju vadyba, 37, 21-35. 
Bloemer, J., \& Ruyter, K. (1998). On the relationship between store image, store satisfaction and store loyalty. European Journal of Marketing, 32 (5/6), 499-513.

Blut, M., Ahlert, D., Backhau, C., \& Evanschitzky, H. (2007, May 22-25). Customer Value, Customer Satisfaction, and Customer Loyalty: An Examination of the Impact and the Multidimensional Nature of Switching Costs. Proceedings of the European Marketing Conference (36), Reykjavik, Iceland.

Bove, L. L., \& Johnson, L. W. (2009). Does “true” personal or service loyalty last? A longitudinal study. Journal of Services Marketing, 23(3), 187-194.

Caruana, A. (2000). Service loyalty: the effects of service quality and the mediating role of customer satisfaction. European Journal of Marketing, 36(7/8), 11-28.

Cunningham, R. M. (1956). Brand Loyalty - What, Where, How Much?. Harvard Business Review, 34(1), $116-128$.

Curranm, J. M., Meuter, M. L., \& Surprenant, C. F. (2003). Intentions to Use Self-Service Technologies: A Confluence of Multiple Attitudes. Journal of Service Research, 5(3), 209 - 224.

Dabholkar, P. A., \& Bagozzi, R. P. (2002). An Attitudinal Model of Technology-Based Self-Service: Moderating Effects of Consumer Traits and Situational Factors. Journal of the Academy of Marketing Science, 30(3), 184-201.

Day, G. S. (1969). A Two-Dimensional Concept of Brand Loyalty. Journal of Academic Research, 9, 29-35.

Dean, D. H. (2008). Shopper age and the use of self-service technologies, Managing Service Quality, 18(3), $225-238$.

Dick, A. S., \& Basu, K. (1994). Customer Loyalty: Toward an Integrated Conceptual Framework. Journal of the Academy of Marketing Science, 22(2), 99-113.

Dikcius, V. (2005). Marketingo tyrimai: Teorija ir praktika (Marketing research: theory and practise). Vilniaus Vadybos Kolegija (Vilnius Management College). Vilnius, $2^{\text {nd }}$ edition.

Dovaliene, A., \& Virvilaite, R. (2008). Customer Value and Its Contribution to the Longevity of Relationship with Service Provider: the Case of Theatre Industry. Inzinerine Ekonomika-Engineering Economics(1), 66-73.

Fornier, S. (1994). A Consumer-based Relationship Framework for Strategic Brand Management, published PhD dissertation, University of Florida.

Gremler, D. D., \& Brown, S.W. (1996). Service Loyalty: Its Nature, Importance, and Implications, In Advancing Service Quality: A Global Perspective, in Edvardsson, B., Brown, S.W., Johnston, R., et al., eds. International Service Quality Association, 171-180.

Hallowell, R. (1996). The relationships of customer satisfaction, customer loyalty, and profitability: an empirical study. International Journal of Service Industry Management, 7(4), 27-42.

Jackson, B. B. (1987). Winning and Keeping Industrial Customers: The Dynamic of Customer Relationships, Lexington, MA: Lexington Books.

Jacoby, J. (1971). A model of multi-brand loyalty. Journal of Advertising Research, 11, 25-31.

Jacoby, J., \& Chestnut, R. W. (1978). Brand Loyalty Measurement and Management, New York, Wiley.

Jacoby, J., \& Kyner, D. B. (1973). Brand Loyalty Versus Repeat Purchase Behavior. Journal of Marketing Research, $10(2), 1-9$.

Keiningham, T. L., Goddard, M. K. M., Vavra, T. G., \& Iaci, A. (1999). Customer Delight and the Bottom-Line. Marketing Management, 8(3), 57-63.

Kuhl, J., \& Beckmann, J. (1985). In: J. Kuhl and J. Beckmann, Editors, Action control: From cognition to behavior, Springer-Verlag, Berlin, Germany.

McKenzie, B. (2006). Retail service quality success factors in Estonia: a qualitative approach. Baltic Journal of Management, 1(3), 352-369.

Meuter, M. L., Ostrom, A. L., Roundtree, R. I., \& Bitner, M. J. (2000). Self-Service Technologies: Understanding Customer Satisfaction with Technology-Based Service Encounters. Journal of Marketing, 64(4), 50-64.

Meuter, M. L., Ostrom, A. L., Bitner, M. J., \& Roundtree, R. (2003). The influence of technology anxiety on consumer use and experiences with self-service technologies. Journal of Business Research, 56(11), 899-907.

Newman, J. W., \& Werbel, R. A. (1973). Multivariate analysis of brand loyalty for major household appliances. Journal of Marketing Research, 10(4), 404-409.

Oliver, R. L. (1999). Whence Consumer Loyalty?. Journal of Marketing, 63, 33-34.

Oliver, R. L. (1997). Satisfaction: A Behavioral Perspective on the Consumer, New York: The McGraw-Hill Companies, Inc.

Selnes, F., \& Håvard, H. (2001). The Potential Hazard of Self-Service in Developing Customer Loyalty. Journal of Service Research, 4(2), 79-90.

Simon, F, \& Usunier, J. C. (2007). Cognitive, demographic, and situational determinants of service customer preference for personnel-in-contact over self-service technology. International Journal of Research in Marketing, 24(2), 163-73. 
Maik Huettinger, Vytenis Cubrinskas. Unmanned Bonds: the Impact of Self-Automated Service on...

Parasuraman, A. (2000). Technology Readiness Index (Tri): A Multiple-Item Scale to Measure Readiness to Embrace New Technologies. Journal of Service Research, 2(4), 307-321.

Prus, A., \& Brandt, R. D. (1995). Understanding your customers. Marketing Tools Magazine, 10-14.

Reinders, M. J., Dabholkar, P. A., \& Frambach, R. T. (2008). "Consequences of Forcing Consumers to Use TechnologyBased Self-Service. Journal of Service Research, 11(2), 107-123.

Weijters, B., Rangarajan, D., Falk, T., \& Schillewaert, N. (2007). Determinants and Outcomes of Customers' Use of SelfService Technology in a Retail Setting. Journal of Service Research, 10(1), 3-23.

Virvilaite, R., Saladiene, V., \& Skindaras, D. (2009). The Relationship between Price and Loyalty in Service Industry. Inzinerine Ekonomika-Engineering Economics(3), 96-104.

Yi, Y. (1990). A critical review of consumer satisfaction, in Zeithaml, V. (ed.). Review of Marketing. American Marketing Association, Chicago, IL, 68-123.

Zikiene, K., \& Bakanauskas, A. P. (2009). Research of Factors Influencing Loyal Customer Switching Behavior. Organizaciju vadyba, 52, 153-170.

Maik Huettinger, Vytenis Čubrinskas

Žmogaus nevaldomi saitai: automatinès savitarnos poveikis pirkẻjų lojalumui

Santrauka

Populiarèjantys savitarnos punktai finansų, ryšių, mažmeninès prekybos ir kituose sektoriuose sukèlė akademinių sluoksnių domėjimąsi aptarnavimo technologijų bei klientų sąveika. Iš paskelbtų tyrimų tyrinėti aspektai apima: savitarnos automatų įsisavinimą arba atmetimą (Parasuraman, 2000, Curran et al, 2003), situacijos ir kitus veiksnius naudojimo procese (Dabholkar ir Bagozzi darbuotojų, 2002), pasitenkinimo naudojimu veiksnius (Meuter et al, 2000) ir amžiaus įtaką (Dean, 2008). Tačiau poveikis lojalumui tyrinètas tik iš dalies (Selnes, 2001).

Savitarna yra tokio tipo paslauga, kai klientas suvokia pirkimo veiksmą kaip asmenišką ir savarankišką dalyvavimą kuriant aptarnavimą. Kadangi klientas daro poveiki pirkimo patirties kokybei, savaime paveikiamas ir imonès ịvaizdis. Lojalumas parduotuvei ar prekei taip pat yra veikiamas paties kliento pastangų ir patirties. Šis klientų pritraukimo ir išlaikymo veiksnys yra svarbus verslo kintamasis.

Vartotojų lojalumas, didejant konkurencijai, tapo svarbia koncepcija marketingo tyrimuose. Imonès diegia lojalumo programas, siekdamos išlaikyti klientus. Vartotojų elgsena, ypač lojalumas, yra pagrindinis strateginio valdymo elementas, leidžiantis bendrovėms sukurti tvirtą pranašumą labai konkurencingoje aplinkoje. Daugiausia ištikimybè yra susijusi su pasitikėjimu ir leidžia imonėms nustatyti šiek tiek didesnes kainas - gaunama nauda, kuri leidžia daugiau investuoti į mokslinius tyrimus ir plètrą.

Anot Oliver, lojalumas yra „gilus“ įsipareigojimas pakartotinai įsigyti arba iš naujo ir nuosekliai proteguoti pageidaujamą produktą (paslauga) ateityje, taip sukeliant kartotini to paties prekinio ženklo (ar prekẻs ženklo asortimento) pirkimą, nepaisant situacijos įtakos ar rinkodaros pastangų, kurios gali sukelti pasikeitusị elgesį“" (Oliver, 1999).

Straipsnis yra aktualus vartotojų elgseną tyrinejjantiems specialistams ir savitarnos technologijų kūrèjams. Tyrimo problematika apima nišą rinkos tyrimuose. Nors lojalumo reiškinys apskritai nèra naujas ar neaptartas, tačiau lojalumas sistemoms ir rekomendacijos pirmiausia naudingos rinkodaros studijoms, taip pat vadybiniams sprendimams prekybos vietose.

Prieš įrengiant savitarnos sistemas bei jas naudojant, prekiautojui reikia išsiaiškinti, ar šios sistemos neatbaidys pirkëjų. Šios sistemos turi ir teigiamą poveikị, kad pritrauktų pirkejjus. Taigi nėra visiškai aišku, kokị poveikị savitarnos automatų paslaugos turi pirkèjų lojalumui.

Tyrimo tikslas - apibréžti Lietuvos vartotojų požiūrị i automatinę savitarną lojalumo požiūriu; suformuoti pagrindą bei duomenų bazę tolesniems tyrimams atlikti.

Tyrimo uždaviniai:

1) apžvelgti literatūrą apie vartotojų ir savitarnos automatinių sistemų sąveiką ir nustatyti esamų žinių spragas ar prieštaravimus.

2) tiksliai nustatyti tyrimo kryptị, remiantis analizuota literatūra ir praktiniu pritaikomumu. Aprašyti vartotojų bruožus, kurie turi įtakos tam tikram požiūriui į savitarnos sistemas.

3) i̇vertinti vartotojų bruožų svarbą aptarnavimo tipui pasirinkti, atlikti statistinę apklausos metu surinktų duomenų analizę. Klasifikuoti bruožus pagal demografines ypatybes.

4) Pateikti rekomendacijas tolesniems tyrimams atlikti, taip pat pateikti praktinio pritaikymo išvadas.

Šiame straipsnyje aptariama klientų lojalumo ir savitarnos technologijų sąveika. Tyrimas grindžiamas 547 respondentų statistine imtimi ir prielaida apie galbūt technologijų skatinamą lojalumą. İvertinti naudojimo būdai ir nuomonès. Rezultatai rodo, kad vartotojai, kurie parodė teigiamą požiūrị i savitarnos automatus, taip pat pozityviau vertina ir paslaugų teikèjus (imones). Sustiprintas teigiamas požiūris i i̇monę, kuri siūlo savitarnos alternatyva, nurodo naujo lojalumo tipo kūrimo krypti.

Respondentai buvo sugrupuoti pagal demografinius rodiklius. Pažymètina, kad jaunesni ir didesnes pajamas gaunantys klientai yra labiau susidomèję su technologiniais sprendimais susijusiu klientų aptarnavimo modeliu.

Tyrimo iškelti tikslai buvo pasiekti: apžvelgus literatūrą, buvo suformuluota hipotezè, vèliau panaudota surinktiems duomenims analizuoti. Ieškomas požymis buvo aptiktas, nustatytas ir įvertintas. Gavus rezultatus padarytos išvados ir pateiktos rekomendacijos kaip spręsti problemą.

Iš atskiros klausimyno dalies apie savitarnos sistemų požymius respondentai nurodè keletą pagrindinių panašumų ir trūkumų. Jie nurodo praktinius patarimus tiek gamintojams, tiek naudotojams, kuriuos savitarnos sistemų ypatumus reikètų pabrèžti reklamoje, kuriuos - pagerinti arba apskritai sukurti nuomonę apie juos.

Pirma, savitarnos sistemų bruožus gana vienodai suvokia tie pirkèjai, kurie naudoja technologijas dažnai, ir tie, kurie jas naudoti vengia. Tai rodo, kad technologija yra pakankamai objektyvi, neiškreipta. Tačiau svarbu žinoti, kokias potencialus klientas turètų akcentuoti savitarnos sistemų savybes, kad jis taptų nuolatiniu naudotoju.

Antra, skirtingos vartotojų grupės (dažnų ir vienkartiniai naudotojai) panašumus suvokia beveik vienodai. Žmonės tiki, kad savitarna yra tai, kas greičiau, patogiau. Taip pat jie tiki, kad ji užtikrina didesni privatumą. Be to, jie mano, kad naudotis savitarnos mašinomis yra smagu. İdomu tai, kad savitarnos mėgèjai labiau vertina paslaugos patogumą, o nenaudojantys šios paslaugos mano, kad smagumas yra viena iš svarbiausių priežasčių naudoti savitarnos sistemas. Loginė išvada - siekiant paskatinti daugiau vartotojų išbandyti savitarną, reikia mažiau akcentuoti, kad tai greita ir įdomu, o labiau akcentuoti, kad tai patogu, lengviau pasiekiamas tikslas. Paprasčiau tariant, jei vartotojai žinotų, kad savitarna yra ne tik žaisminga priemonė parduotuvejje, bet iš tikrujų tinkamas darbo pagrindas skirtas poreikiams tenkinti, imonè gali tikètis daugiau vartotojų, kurie apsispręstų, kokią rinktis paslaugą konkrečioje situacijoje, o ne vadovautųsi „darau kaip visuomet“ taisykle.

Kita vertus, didelis savitarnos automatų trūkumas - „nèra galimybės konsultuotis“. Funkcionalumas gali atbaidyti kai kuriuos naudotojus, kurie gali būti susirūpinę mažu lankstumu (nuolaidų kortelès) arba prarastais priedais (nuolaidų kuponai). Tai tipinès papildomos veiklos, kurias atlieka personalas. 
Inzinerine Ekonomika-Engineering Economics, 2011, 22(2), 203-213

Todèl rinkodaros pranešimu reikia sustiprinti techninę (naudojimo paprastumas ir daug funkcijų) pusę, užtikrinant, kad klientai nepraras jokių paslaugų ir priedų.

Svarbiausias klausimas apie naujas technologijas yra faktinis vartotojų segmentas, kuris, labiausiai tikètina, galètų būti suinteresuotas jas išbandyti. Todèl tyrime surinkti demografiniai respondentu duomenys, siekiant vèliau klasifikuoti ir pateikti tam tikrų kategoriju modelius. Imtis yra pakankamai ivvairi demografijos požiūriu, todèl rezultatai tinka platesniam apibendrinimui. Išsamesni duomenys pateikiami diagramose. Nenuostabu, kad rinkodaros pastangų tikslas turètų būti jaunesni (iki 35 metų) žmonès. Išsilavinimo veiksnys nėra vienakryptis: studentus ir universitetų absolventus naujovės traukia labiau - tyrimo rezultatais tai patvirtinta. Kita vertus asmenys, turintys vidurinės mokyklos ar kolegijos išsilavinimą yra mažiau entuziastingi savitarnos sistemų atžvilgiu.

Nors tiek kolegijos, tiek universitetinis išsilavinimas yra aukštasis, tačiau gana kolegijų ir universitetų absolventų nuomonė apie savitarną skiriasi. Preferencijos (tarp savitarnos ir iprasto aptarnavimo) skirtumas yra daugiau kaip $20 \%$ tarp šių išsilavinimo kategorijų.

Kategorija „nebaigtas aukštasis išsilavinimas“ nèra labai tiksli, dèl lietuviškos formuluotès klausimyne. Gali būti, kad kai kurie dar studijuojantys respondentai nurodè, kad jų išsilavinimas - nebaigtas aukštasis.

Kitas aspektas - lojalumas technologiniams sprendimams. Remiantis stebejjimais, nei amžius nei išsilavinimas nèra tiesiogiai priklausomi požymiai. Tačiau šeimos sudètis atlieka gana svarbų vaidmenị. Galima spèti, kad yra tam tikrų psichologinių priežasčių. Pavyzdžiui, skirtingai elgiasi jauni žmonès, kurie jau turi šeimas, ir tie žmonès, kurie jų dar neturi. Nevienodai elgiasi asmenys, kurie gyvena su savo tèvais ir tie asmenys, kurie gyvena savarankiškai. Paprastai žmonès, kurie yra mažiau šeimyniški, parodè, kad labiau lojalūs technologiniams sprendimams. Teoriškai pomėgis naudotis savitarna gali būti susijęs su asmens savarankiškumu platesne prasme.

Galiausiai ryškus technologinio lojalumo rodiklis yra pajamų koeficientas. Technologijomis paremtas lojalumo bruožas yra beveik tiesiogiai priklausomas nuo mènesiniu pajamų: kuo jos didesnès, tuo labiau „technologiškai ištikimas“ yra respondentas. Kita svarbi pastaba yra tai, kad aukščiausios pajamų kategorijos (> $2000 \mathrm{Lt}$ ) respondentai maždaug $20 \%$ dažniau pasirenka savitarną nei darbuotojo aptarnavimą. Tai yra svarbu egzistuoja du klientų segmentai, kuriuose savitarnos populiarinimas būtu rezultatyvus. Šie segmentai yra tokie: a) jauni, nepriklausomi žmonès arba b) žmonės, gaunantys didesnes pajamas (nepaisant amžiaus). Tai grupes, kurios, tikètina, i̇vertintų naują savitarnos alternatyvą palankiausiai. Tai sukuria palankesnị požiūri i i imonę ir didina lojalumą, tenkinant specifinius klientų poreikius.

Raktažodžiai: automatai, asmeninis aptarnavimas, lojalumas, savitarna, technologija, vartotojai.

The article has been reviewed.

Received in December, 2010; accepted in April, 2011. 